\title{
Intuition, Research, and the Academic Library
}

In 1933, Pierce Butler lamented the fact that the library profession appeared to be almost anti-intellectual in its approach to library problems and seemed to stand alone in the "simplicity of its pragmatism." In 1973, we find Jesse Shera stoically referring to research as an activity "largely foreign to a profession oriented toward service rather than analysis of bibliothecal phenomena or introspection of its own activity." I fully agree with both men when they argue that the library profession has been generally uninterested in research, and I am also convinced that we have reached a point where no substantive gains in the quality of library service will be possible without the initiation of a systematic, aggressive, and longterm research effort. We simply will not see any major advances in theory or practice if we continue to rely on the intuitive infallibility of the professional in the field as we have in the past. This approach appears to be bankrupt.

If one accepts this premise, and it seems to me to be incontrovertable, it follows that research in library and information science, and the intelligent utilization of research findings, become the key to any real progress.

But how, in the face of the economic and socio-political constraints currently facing the profession, can such a research effort be initiated? It appears obvious that the library schools with their small faculties, large enrollments, and practical/technical emphasis, are incapable of undertaking a long-term or large-scale research program. At best, they may be able to train adequately a generation of scholars to fill research positions elsewhere. Similarly, the research institutes which showed some promise several years ago now are dying in the wake of the withdrawal of federal support for research in library and information science.

It now appears that there is only one institution capable of sustaining a research program of the size and extent envisioned here; that is, the American academic library. If the top 500 university and college libraries in this country were to provide shelter for a research/systems office under their organizational umbrellas, a considerable research component might thus be established. The individuals involved, who hopefully would be encouraged to undertake basic as well as applied research, might well constitute a tenfold increase in the size of the research wing of the profession.

Of course, this idea is hardly more than a pipe dream unless academic librarians are willing to commit a part of their resources to an ongoing research program. While they generally have not been willing to do so in the past, there does seem to be evidence of an intensifying interest in this issue among contemporary academic librarians. Perhaps a new age is dawning.

Michael H. HARRIS 